\title{
PENGARUH TERAPI BERMAIN POP- UP BOOK TERHADAP KECEMASAN PREOPERATIF MENGGUNAKAN ANESTESI UMUM PADA ANAK USIA SEKOLAH DI RS PKU MUHAMMADIYAH YOGYAKARTA
}

\author{
Nia Handayani ${ }^{1}$, Atik Badi'ah ${ }^{2}$, Budhy Ermawan ${ }^{3}$ \\ Email: niahandayani19@gmail.com
}

\begin{abstract}
A play therapy will release the child from a variety of unpleasant feelings, such as anger, fear, anxiety, and pain. In the United States,> 4 million children undergo surgery each year and it is estimated that $50 \%-75 \%$ of these show fear and anxiety before surgery (Kain \& Alison, 2005). The state of anxious child in the face of surgery will. Research aim to know the influence of pop up book media play therapy on preoperative anxiety level using general anesthesia in school-aged children in PKU Muhammadiyah Hospital Yogyakarta. Method use pre experimental type of study with one group pre test and post test without using control group. Sampling technique with purposive sampling as many as 20 patients of school-age children pre operative with general anesthesia. Data collected was then analysed using Wilcoxon Rank Test. The result pre-test therapy showed moderate anxiety as many as 13 people $(65 \%)$, post-test play therapy showed moderate anxiety as much as 10 people $(50 \%)$, decreased in severe anxiety and an increase in mild anxiety by 9 people (45\%. Wilcoxon Rank Test test results known level of significance $\rho=0,000$ $(\rho<0.05)$. The conclusion there is an influence of pop up book media play therapy on preoperative anxiety level using general anesthesia to school-aged children in PKU Muhammadiyah Hospital Yogyakarta.
\end{abstract}

Keywords: play therapy, anxiety, school-aged children, preoperative.

\begin{abstract}
ABSTRAK
Terapi bermain akan melepaskan anak dari berbagai perasaan tidak menyenangkan, seperti marah, takut, kecemasan, dan nyeri. Di AS, > 4 juta anak menjalani operasi setiap tahunnya dan diperkirakan bahwa 50\% - 75\% dari mereka ini menunjukkan rasa takut dan kecemasan sebelum operasi (Kain \& Alison, 2005). Keadaan anak yang cemas dalam menghadapi operasi akan menghambat jalannya operasi, salah satunya menyebabkan respon terhadap obat-obatan anestesi tidak adekuat. Tujuan dari penelitian ini diketahuinya pengaruh terapi bermain media pop-up book terhadap tingkat kecemasan pre operatif menggunakan anestesi umum pada anak usia sekolah di RS PKU Muhammadiyah Yogyakarta. Jenis penelitian praeksperimen dengan desain one group pre test and post test tanpa menggunakan kelompok kontrol. Teknik pengambilan sampel dengan purposive sampling sebanyak 20 pasien anak usia sekolah pre operatif dengan anestesi umum. Analisis menggunakan Wilcoxon Rank Test. Hasil pre test menunjukkan cemas sedang sebanyak 13 orang $(65 \%)$, post test menunjukkan cemas sedang sebanyak 10 orang $(50 \%)$, terjadi penurunan pada cemas berat dan terjadi peningkatan pada cemas ringan sebesar 9 orang $(45 \%)$. Hasil uji Wilcoxon Rank Test diketahui tingkat signifikansi $\rho=0,000(\rho<0,05)$. Kesimpulannya ada pengaruh terapi bermain media pop-up book terhadap tingkat kecemasan preoperatif menggunakan anestesi umum pada anak usia sekolah di RS PKU Muhammadiyah Yogyakarta.
\end{abstract}

Kata kunci: terapi bermain, kecemasan, anak usia sekolah, preoperatif. 


\section{PENDAHULUAN}

Bermain merupakan salah satu strategi mempersiapkan anak dalam upaya meningkatkan keakraban dengan prosedur tindakan medis sehingga dapat menurunkan kecemasan. ${ }^{1}$ Permainan hospital story, kehadiran peer, therapeutic peer play, biblioterapi, dan boneka simulasi terapeutik merupakan beberapa teknik bermain untuk mengatasi kecemasan anak. ${ }^{2}$

Pop-up book adalah konstruksi, pergerakan buku yang muncul dari halaman yang membuat kita terkejut dan menyenangkan. Pop-up book identik dengan anak-anak dan mainan, namun benda ini dapat digunakan menjadi media pembelajaran yang baik yang berisi cerita bergambar yang memiliki bentuk tiga dimensi ketika halaman buku dibuka. ${ }^{3}$

Di Amerika Serikat, lebih dari 4 juta anak menjalani operasi setiap tahunnya dan diperkirakan bahwa 50\% - 75\% dari mereka ini menunjukkan rasa takut dan kecemasan sebelum operasi. Pemahaman dan manajemen kecemasan sebelum operasi yang tepat penting karena tingkat kecemasan yang tinggi dapat menyebabkan perubahan psikologis dan fisiologis yang merugikan. ${ }^{4}$ Akibat dari kecemasan menyebabkan gangguan tidur, mual, kelelahan dan tidak adekuatnya respon terhadap obat-obatan anestesi dan analgesia. ${ }^{5}$

Penelitian pada 37 responden anak yang akan menjalani operasi di RS PKU Muhammadiyah Yogyakarta terdapat faktor risiko yang mempengaruhi kecemasan pra operasi antara lain: jenis kelamin, orang tua, lingkungan pre operatif. ${ }^{6}$

Dari hasil studi pendahuluan yang sudah dilakukan pada tanggal 10 Maret 2017 diperoleh data anak usia sekolah yang melakukan operasi menggunakan anestesi umum di RS PKU Muhammadiyah Yogyakarta tercatat dari bulan Desember tahun 2016 hingga Februari 2017 kurang lebih ada 30 anak. Berdasarkan wawancara dengan perawat anestesi di ruang persiapan IBS dengan 3 pasien pra operasi, 1 pasien anak terlihat menangis dan menolak masuk ke ruang persiapan karena tidak mau lepas dari ibunya, 2 anak mengatakan takut masuk ke ruang operasi. 
Berdasarkan latar belakang di atas, peneliti tertarik untuk mengambil judul "Pengaruh Terapi Bermain Pop-up Book Terhadap Kecemasan Preoperatif Menggunakan Anestesi Umum pada Anak Usia Sekolah di RS PKU Muhammadiyah Yogyakarta".

\section{METODE PENELITIAN}

Jenis penelitian ini merupakan penelitian praeksperimen, dengan desain one group pre test and post test. Rancangan penelitian ini juga tidak ada kelompok pembanding (kontrol). Teknik penentuan sampel yang peneliti gunakan consecutive sampling.

Pengambilan sampel selama 2 bulan sehingga populasi awal pada penelitian ini adalah 20 anak dengan kriteria inklusi: anak usia sekolah (6-12 tahun), pasien yang akan dilakukan pembedahan dengan anestesi umum, status fisik ASA I-II, prosedur bedah elektif, anak dalam keadaan sadar dan kooperatif, dan bersedia menjadi responden. Pengambilan data berlangsung pada bulan Mei-Juni 2017 dilakukan di bangsal Ibnu Sina. Instrumen yang digunakan adalah kuesioner Chinese Version State Anxiety Scale for Children (CSAS-C) yang terdiri dari 20 pertanyaan dengan kriteria hasilnya: ringan, sedang, berat, dan berat sekali, media pop-up book dengan tema my operation dan jalan-jalan, dan surat persetujuan menjadi responden. Pasien yang masuk dalam kriteria inklusi setelah dilakukan informed consent kemudian dilakukan tes tingkat kecemasan (pre test) dengan CSAS-C lalu diberi terapi bermain pop-up book dan yang terakhir dilakukan tes tingkat kecemasan (post test) dengan CSAS-C. Data hasil penelitian kemudian diuji dengan analisis univariat deskriptif dan analisis bivariat uji hipotesa Wilcoxon Rank Test (uji non parametrik).

\section{HASIL DAN PEMBAHASAN}

\section{Karakteristik Responden Anak Usia Sekolah}

Responden yang digunakan dalam penelitian ini adalah pasien anak usia sekolah (6-12 tahun) yang akan menjalani prosedur bedah elektif dengan teknik anestesi umum pada waktu yang telah ditentukan di RS PKU Muhammadiyah Yogyakarta yang berjumlah 20 responden. 
Tabel 2. Distribusi Frekuensi Karakteristik Responden Sebelum dan Sesudah Pemberian Pop-up Book

\begin{tabular}{lcr}
\hline \multicolumn{1}{r}{ Karakteristik } & Frekuensi (f) & Persentas \\
\hline Jenis Kelamin & & \\
a. Laki-laki & 11 & 55 \\
b. Perempuan & 9 & 45 \\
Usia (tahun) & & \\
a. 6-8 & 13 & 65 \\
b. 9-12 & 7 & 35 \\
Pendidikan SD & 13 & 65 \\
a. I-III & 7 & 35 \\
b. IV-VI & &
\end{tabular}

Pengalaman masuk RS

a. Pernah

b. Belum pernah

420

Jenis Operasi

a. Apendisitis

b. Fraktur

$16 \quad 80$

c. Tonsilitis

d. STT

e. Katarak

f. Hernia Inguinal

g. Hidronefrosis

h. Acrodermatitis

i. GEA

Total

$\begin{array}{lc}5 & 25 \\ 5 & 25 \\ 3 & 15 \\ 2 & 10 \\ 1 & 5 \\ 1 & 5 \\ 1 & 5 \\ 1 & 5 \\ 1 & 5 \\ \mathbf{2 0} & \mathbf{1 0 0}\end{array}$

Tabel 2 diketahui bahwa sebagian besar responden berjenis kelamin laki-laki sebesar 11 orang (55\%), berusia antara 6-8 tahun sebesar 13 orang (65\%), duduk di kelas I-III SD sebesar 13 orang (65\%), belum pernah masuk RS sebesar 16 orang (80\%), dan jenis operasi apendisitis dan fraktur sama besar yaitu masing-masing 5 orang $(25 \%)$.

\section{Kecemasan Sebelum \& Sesudah Terapi Bermain}

Distribusi responden berdasarkan kecemasan anak usia sekolah 6-12 tahun preoperatif menggunakan anestesi umum sebelum dan sesudah diberi terapi bermain pop-up book pada penelitian ini adalah sebagai berikut seperti tabel 3 .

Tabel 3. Distribusi Frekuensi Kecemasan Anak Usia Sekolah Preoperatif Menggunakan Anestesi Umum Sebelum dan Sesudah Diberi Pop-up Book

\begin{tabular}{lcccc}
\hline \multicolumn{1}{c}{ Kriteria Kecemasan Anak } & Pre test & \multicolumn{2}{c}{ Post test } \\
& f & \% & f & \% \\
\hline Kecemasan ringan & 1 & 5 & 9 & 45 \\
Kecemasan sedang & 13 & 65 & 10 & 50 \\
Kecemasan berat & 6 & 30 & 1 & 5 \\
Kecemasan berat sekali (panik) & 0 & 0 & 0 & 0 \\
$\quad$ Total & 20 & 100 & 20 & 100 \\
\hline
\end{tabular}


Berdasarkan data yang tertera pada tabel 3, kecemasan sebelum pemberian pop-up book di RS PKU Muhammadiyah Yogyakarta sebagian besar yaitu 13 orang $(65 \%)$ dengan kategori cemas sedang. Adapun kategori cemas berat sekali tidak ada dan kategori paling sedikit yaitu cemas ringan sebesar 1 orang (5\%). Kecemasan sesudah pemberian pop-up book sebagian besar yaitu 10 orang (50\%) cemas sedang, dan paling sedikit 1 orang $(5 \%)$ dengan cemas berat, nampak terjadi penurunan pada kategori cemas berat, dan terjadi peningkatan pada kategori cemas ringan 9 orang $(45 \%)$.

\section{Kecemasan Sebelum \& Sesudah Terapi Bermain Berdasarkan Jenis Kelamin}

Tabulasi silang kecemasan anak usia sekolah preoperatif menggunakan anestesi umum sebelum dan sesudah diberi terapi bermain pop-up book berdasarkan jenis kelamin responden adalah sebagai berikut.

Tabel 4. Tabulasi Silang Kecemasan Sebelum Pemberian Pop-up Book Berdasarkan Jenis Kelamin

\begin{tabular}{ccccccccc}
\hline \multirow{2}{*}{ Jenis Kel } & \multicolumn{9}{c}{ Tingkat Kecemasan } & \multicolumn{2}{c}{ Total } \\
& \multicolumn{1}{c}{$\mathrm{R}$} & $\%$ & $\mathrm{f}$ & $\%$ & $\mathrm{f}$ & $\%$ & $\mathrm{f}$ & $\%$ \\
\cline { 2 - 10 } & $\mathrm{f}$ & 11,1 & 6 & 66,7 & 2 & 22,2 & 9 & 100 \\
\hline $\mathbf{P}$ & 1 & 0 & 7 & 63,6 & 4 & 36,4 & 11 & 100 \\
\hline
\end{tabular}

Ket:

$\begin{array}{ll}\text { R: Ringan } & \text { B: Berat } \\ \text { S: Sedang } & \text { BS: Berat Sekali }\end{array}$

Tabel 5. Tabulasi Silang Kecemasan Sesudah Pemberian Pop-up Book Berdasarkan Jenis Kelamin

\begin{tabular}{ccccccccc}
\hline & \multicolumn{9}{c}{ Tingkat Kecemasan } & \multicolumn{2}{c}{ Total } \\
Jenis Kel & & $\mathrm{R}$ & \multicolumn{2}{c}{$\mathrm{S}$} & \multicolumn{2}{c}{ B } & $\mathrm{f}$ & $\%$ \\
& $\mathrm{f}$ & $\%$ & $\mathrm{f}$ & $\%$ & $\mathrm{f}$ & $\%$ & 9 & 100 \\
\hline P & 5 & 55,6 & 4 & 44,4 & 0 & 0 & 11 & 100 \\
\hline L & 4 & 36,4 & 6 & 54,5 & 1 & 9,1 & 11 \\
\hline
\end{tabular}

Berdasarkan data yang tertera pada tabel 4 dan 5, dapat diketahui bahwa anak laki-laki maupun perempuan umur 6-12 tahun sebelum pemberian terapi bermain sebagian besar mengalami kecemasan sedang, masing-masing sebesar 7 orang $(63,6 \%)$ dan 6 orang $(66,7 \%)$. Tingkat kecemasan yang paling sedikit dialami laki-laki dengan gejala kecemasan berat yaitu 4 orang $(36,4 \%)$, sedangkan anak perempuan mengalami gejala kecemasan ringan 1 orang $(11,1 \%)$. Kecemasan sesudah pemberian pop-up book masing-masing mengalami 
penurunan gejala kecemasan, yaitu anak laki-laki paling banyak dengan gejala kecemasan sedang 6 orang $(54,5 \%)$ dan anak perempuan gejala kecemasan ringan 5 orang $(55,6 \%)$. Tingkat kecemasan yang paling sedikit dialami laki-laki dengan gejala kecemasan berat yaitu 1 orang $(9,1 \%)$, sedangkan anak perempuan mengalami gejala kecemasan sedang 4 orang $(44,4 \%)$.

\section{Kecemasan Sebelum \& Sesudah Terapi Bermain Berdasarkan Usia}

Tabulasi silang kecemasan anak usia sekolah preoperatif menggunakan anestesi umum sebelum dan sesudah diberi terapi bermain pop-up book berdasarkan usia responden pada penelitian ini adalah sebagai berikut.

Tabel 6. Tabulasi Silang Kecemasan Sebelum Pemberian Pop-up Book Berdasarkan Usia

\begin{tabular}{|c|c|c|c|c|c|c|c|c|}
\hline \multirow{3}{*}{ Usia (th) } & \multicolumn{6}{|c|}{ Tingkat Kecemasan } & \multicolumn{2}{|c|}{ Total } \\
\hline & \multicolumn{2}{|r|}{$\mathrm{R}$} & \multicolumn{2}{|r|}{$\mathrm{S}$} & \multicolumn{2}{|r|}{ B } & & \\
\hline & $\mathrm{f}$ & $\%$ & $\mathrm{f}$ & $\%$ & $f$ & $\%$ & $\mathrm{f}$ & $\%$ \\
\hline 6-8 & 0 & 0 & 9 & 69,2 & 4 & 30,8 & 13 & 100 \\
\hline $9-12$ & 1 & 14,3 & 4 & 57,1 & 2 & 28,6 & 7 & 100 \\
\hline
\end{tabular}

Tabel 7. Tabulasi Silang Kecemasan Sesudah Pemberian Pop-up Book Berdasarkan Usia

\begin{tabular}{lcccccccc}
\hline \multirow{2}{*}{$\begin{array}{c}\text { Usia } \\
\text { (th) }\end{array}$} & \multicolumn{9}{c}{ Tingkat Kecemasan } & \multicolumn{2}{c}{ Total } \\
\cline { 2 - 9 } & & $\mathrm{R}$ & \multicolumn{3}{c}{$\mathrm{S}$} & $\mathrm{B}$ & $\mathrm{f}$ & $\%$ \\
\cline { 2 - 9 } & $\mathrm{f}$ & $\%$ & $\mathrm{f}$ & $\%$ & $\mathrm{f}$ & $\%$ & 13 & 100 \\
\hline $\mathbf{6 - 8}$ & 4 & 30,8 & 8 & 61,5 & 1 & 7,7 & 7 & 100 \\
\hline $\mathbf{9 - 1 2}$ & 5 & 71,4 & 2 & 28,6 & 0 & 0 & \\
\hline
\end{tabular}

Berdasarkan data yang tertera pada tabel 6 dan 7, dapat diketahui bahwa anak dengan usia 6-8 tahun maupun 9-12 tahun sebelum pemberian pop-up book sebagian besar mengalami gejala kecemasan sedang, masing-masing sebesar 9 orang $(69,2 \%)$ dan 4 orang $(57,1 \%)$. Kecemasan sesudah pemberian pop-up book sebagian besar masing-masing mengalami gejala kecemasan sedang sebesar 8 orang $(61,5 \%)$ dan gejala kecemasan ringan sebesar 5 orang $(30,8 \%)$.

\section{Kecemasan Sebelum \& Sesudah Terapi Bermain Berdasarkan Usia}

Tabulasi silang kecemasan anak usia sekolah preoperatif menggunakan anestesi umum sebelum dan sesudah diberi terapi bermain pop-up book berdasarkan tingkat pendidikan responden pada penelitian ini adalah sebagai berikut. 
Tabel 8. Tabulasi Silang Kecemasan Sebelum Pemberian Pop-up Book Berdasarkan Tingkat Pendidikan SD

\begin{tabular}{ccccccccc}
\hline \multirow{2}{*}{ Pend SD } & \multicolumn{9}{c}{ Tingkat Kecemasan } & \multicolumn{3}{c}{ Total } \\
& f & $\%$ & f & $\%$ & f & $\%$ & f & $\%$ \\
\hline Kls & 0 & 0 & 9 & 69,2 & 4 & 30,8 & 13 & 100 \\
$\mathbf{1 - 3}$ & 1 & 14,3 & 4 & 57,1 & 2 & 28,6 & 7 & 100 \\
\hline $\begin{array}{l}\text { Kls } \\
\text { 4-6 }\end{array}$ & 1 & &
\end{tabular}

Tabel 9. Tabulasi Silang Tingkat Kecemasan Sesudah Pemberian Pop-up Book Berdasarkan Tingkat Pendidikan SD

\begin{tabular}{|c|c|c|c|c|c|c|c|c|}
\hline \multirow{3}{*}{ Pend SD } & \multicolumn{6}{|c|}{ Tingkat Kecemasan } & \multicolumn{2}{|c|}{ Total } \\
\hline & & $\mathbf{R}$ & & $\mathbf{S}$ & & B & & \\
\hline & f & $\%$ & $\mathbf{f}$ & $\%$ & f & $\%$ & $\mathbf{f}$ & $\%$ \\
\hline $\begin{array}{l}\text { Kls } \\
1-3\end{array}$ & 4 & 30,8 & 8 & 61,5 & 1 & 7,7 & 13 & 100 \\
\hline $\begin{array}{l}\text { Kls } \\
4-6\end{array}$ & 5 & 71,4 & 2 & 28,6 & 0 & 0 & 7 & 100 \\
\hline
\end{tabular}

Tabel 8 dan 9, dapat diketahui bahwa anak dengan usia 6-12 tahun yang duduk di kelas 1-3 SD maupun kelas 4-6 SD sebelum pemberian pop-up book sebagian besar mengalami gejala kecemasan sedang masing-masing sebesar 9 orang $(69,2 \%)$ dan 4 orang $(57,1 \%)$. Kecemasan sesudah pemberian pop-up book sebagian besar masing-masing mengalami gejala kecemasan sedang sebesar 8 orang $(61,5 \%)$ dan gejala kecemasan ringan sebesar 5 orang $(71,4 \%)$.

\section{Kecemasan Sebelum \& Sesudah Terapi Bermain Berdasarkan Pengalaman}

\section{Masuk RS}

Tabulasi silang kecemasan anak usia sekolah preoperatif menggunakan anestesi umum sebelum diberi terapi bermain pop-up book berdasarkan pengalaman masuk RS pada penelitian ini adalah sebagai berikut.

Tabel 10. Tabulasi Silang Kecemasan Sebelum Pemberian Pop-up Book Berdasarkan Pengalaman Masuk RS

\begin{tabular}{ccccccccc}
\hline Peng. Masuk RS & \multicolumn{4}{c}{ Tingkat Kecemasan } & \multicolumn{2}{c}{ Total } \\
& & $\mathrm{R}$ & \multicolumn{2}{c}{$\mathrm{S}$} & \multicolumn{3}{c}{$\mathrm{B}$} & \multicolumn{2}{c}{. } \\
& $\mathrm{f}$ & $\%$ & $\mathrm{f}$ & $\%$ & $\mathrm{f}$ & $\%$ & $\mathrm{f}$ & $\%$ \\
\hline Pernah & 1 & 25 & 2 & 50 & 1 & 25 & 4 & 100 \\
\hline Belum & 0 & 0 & 11 & 68,8 & 5 & 31,3 & 16 & 100 \\
\hline
\end{tabular}


Tabel 11. Tabulasi Silang Kecemasan Sesudah Pemberian Pop-up Book Berdasarkan Pengalaman Masuk RS

\begin{tabular}{ccccccccc}
\hline Peng. & \multicolumn{9}{c}{ Tingkat Kecemasan } & \multicolumn{2}{c}{ Total } \\
Masuk RS & f & $\%$ & f & $\%$ & f & $\%$ & f & $\%$ \\
\hline Pernah & 3 & 75 & 1 & 25 & 0 & 0 & 4 & 100 \\
\hline Belum & 6 & 37,5 & 9 & 56,3 & 1 & 6,3 & 16 & 100 \\
\hline
\end{tabular}

Tabel 10 dan 11 dapat diketahui bahwa anak dengan usia 6-12 tahun yang pernah masuk RS sebagian besar mengalami gejala kecemasan sedang sebesar 2 orang (50\%). Anak usia 6-12 tahun yang belum pernah masuk RS sebagian besar mengalami kecemasan dengan gejala sedang sebesar 11 orang $(68,8 \%)$. Kecemasan sesudah diberi terapi bermain pop-up book pada anak usia sekolah yang pernah masuk RS sebagian besar mengalami gejala cemas ringan sebesar 3 orang $(75 \%)$ dan gejala sedang 1 orang $(25 \%)$, sedangkan yang belum pernah masuk RS sebagian besar mengalami gejala kecemasan sedang sebesar 9 orang $(56,3 \%)$ dan paling sedikit mengalami gejala kecemasan berat 1 orang $(6,3 \%)$.

\section{Kecemasan Sebelum \& Sesudah Terapi Bermain Berdasarkan Jenis Operasi}

Tabulasi silang kecemasan anak usia sekolah preoperatif menggunakan anestesi umum sebelum diberi terapi bermain pop-up book berdasarkan jenis operasi pada penelitian ini adalah sebagai berikut.

Tabel 12. Tabulasi Silang Kecemasan Sebelum Pemberian Pop-up Book Berdasarkan Jenis Operasi

\begin{tabular}{|c|c|c|c|c|c|c|c|c|}
\hline \multirow{3}{*}{ Operasi } & \multicolumn{6}{|c|}{ Tingkat Kecemasan } & \multicolumn{2}{|c|}{ Total } \\
\hline & \multicolumn{2}{|r|}{$\mathrm{R}$} & \multicolumn{2}{|r|}{$\mathrm{S}$} & \multicolumn{2}{|r|}{ B } & \multirow[b]{2}{*}{$\mathrm{f}$} & \multirow[b]{2}{*}{$\%$} \\
\hline & $\mathrm{f}$ & $\%$ & $\mathrm{f}$ & $\%$ & $\mathrm{f}$ & $\%$ & & \\
\hline Apendisitis & 0 & 0 & 4 & 80 & 1 & 20 & 5 & 100 \\
\hline Fraktur & 0 & 0 & 3 & 60 & 2 & 40 & 5 & 100 \\
\hline Tonsilitis & 0 & 0 & 1 & 33,3 & 2 & 66,7 & 3 & 100 \\
\hline STT & 0 & 0 & 2 & 100 & 0 & 0 & 2 & 100 \\
\hline Katarak & 1 & 100 & 0 & 0 & 0 & 0 & 1 & 100 \\
\hline Hernia Inguinal & 0 & 0 & 0 & 0 & 1 & 100 & 1 & 100 \\
\hline Hidronefrosis & 0 & 0 & 1 & 100 & 0 & 0 & 1 & 100 \\
\hline Acrodermatitis & 0 & 0 & 1 & 100 & 0 & 0 & 1 & 100 \\
\hline GEA & 0 & 0 & 1 & 100 & 0 & 0 & 1 & 100 \\
\hline
\end{tabular}


Tabel 13. Tabulasi Silang Kecemasan Sesudah Pemberian Pop-up Book Berdasarkan Jenis Operasi

\begin{tabular}{|c|c|c|c|c|c|c|c|c|}
\hline \multirow{3}{*}{ Operasi } & \multicolumn{6}{|c|}{ Tingkat Kecemasan } & \multicolumn{2}{|c|}{ Total } \\
\hline & \multicolumn{2}{|r|}{$\mathrm{R}$} & \multicolumn{2}{|r|}{ S } & \multicolumn{2}{|c|}{$\mathrm{B}$} & & \\
\hline & $\mathrm{f}$ & $\%$ & $\mathrm{f}$ & $\%$ & $\mathrm{f}$ & $\%$ & $f$ & $\%$ \\
\hline Apendisitis & 3 & 60 & 2 & 40 & 0 & 0 & 5 & 100 \\
\hline Fraktur & 2 & 40 & 3 & 60 & 0 & 0 & 5 & 100 \\
\hline Tonsilitis & 1 & 33,3 & 2 & 66,7 & 0 & 0 & 3 & 100 \\
\hline STT & 2 & 100 & 0 & 0 & 0 & 0 & 2 & 100 \\
\hline Katarak & 1 & 100 & 0 & 0 & 0 & 0 & 1 & 100 \\
\hline Hernia Inguinal & 0 & 0 & 0 & 0 & 1 & 100 & 1 & 100 \\
\hline Hidronefrosis & 0 & 0 & 1 & 100 & 0 & 0 & 1 & 100 \\
\hline Acrodermatitis & 0 & 0 & 1 & 100 & 0 & 0 & 1 & 100 \\
\hline GEA & 0 & 0 & 1 & 100 & 0 & 0 & 1 & 100 \\
\hline
\end{tabular}

Berdasarkan data yang tertera pada tabel 12 dan 13, dapat diketahui bahwa anak dengan usia 6-12 tahun sebelum diberi pop-up book sebagian besar menjalani operasi apendisitis dengan gejala kecemasan sedang sebesar 4 orang (80\%), sedangkan sesudah diberi pop-up book sebagian besar menjalani operasi apendisitis dan fraktur dengan gejala kecemasan ringan dan sedang, masingmasing sebesar 3 orang (60\%).

\section{Kecemasan Usia Sekolah Sebelum Dan Sesudah Pemberian Pop-Up Book}

Analisis yang digunakan untuk mengetahui ada tidaknya pengaruh pemberian terapi bermain pop-up book terhadap kecemasan preoperatif menggunakan anestesi umum pada anak usia sekolah yaitu dengan Wilcoxon Rank Test. Uji statistik dalam penelitian ini menggunakan bantuan program komputer yaitu SPSS. Berikut ini adalah hasil Wilcoxon Rank Test :

Tabel 14. Uji Beda Wilcoxon Kecemasan Anak Usia Sekolah Sebelum dan Sesudah Pemberian Terapi Bermain Pop-Up Book

\begin{tabular}{|c|c|c|c|c|c|c|c|c|c|c|c|}
\hline \multirow{3}{*}{ Var } & \multicolumn{8}{|c|}{ Tingkat Kecemasan } & \multicolumn{2}{|c|}{ Total } & \multirow[t]{3}{*}{$\boldsymbol{\rho}$} \\
\hline & \multicolumn{2}{|c|}{$\mathbf{R}$} & \multicolumn{2}{|c|}{$\mathbf{S}$} & \multicolumn{2}{|c|}{ B } & \multicolumn{2}{|c|}{ BS } & & & \\
\hline & f & $\%$ & f & $\%$ & f & $\%$ & f & $\%$ & f & $\%$ & \\
\hline Pre test & 1 & 5 & 13 & 65 & 6 & 30 & 0 & 0 & 20 & $\begin{array}{c}10 \\
0\end{array}$ & 0,000 \\
\hline Post test & 9 & 45 & 10 & 50 & 1 & 5 & 0 & 0 & 20 & $\begin{array}{c}10 \\
0\end{array}$ & \\
\hline
\end{tabular}

Ket:

$\begin{array}{ll}\text { R: Ringan } & \text { B: Berat } \\ \text { S: Sedang } & \text { BS: Berat Sekali }\end{array}$

Tabel 14 kecemasan sesudah diberi terapi bermain pop-up book sebagian besar mengalami kecemasan dengan gejala sedang yaitu sebesar 10 orang (50\%). Terjadi penurunan pada gejala cemas berat yang sebelumnya 6 orang (30\%) 
menurun menjadi 1 orang (5\%) dan terjadi peningkatan pada gejala cemas ringan yang sebelum diberi terapi bermain pop-up book sebesar 1 orang (5\%) menjadi 9 orang $(45 \%)$.

\section{PEMBAHASAN}

Perawatan di RS yang dialami oleh seorang anak dapat menimbulkan berbagai pengalaman yang sangat traumatik dan penuh dengan kecemasan. Cemas yang muncul disebabkan oleh banyak faktor seperti lingkungan fisik rumah sakit antara lain bangunan/ruang rawat, alat-alat, bau yang khas, pakaian putih petugas kesehatan maupun lingkungan sosial, seperti sesama pasien anak, ataupun interaksi dan sikap petugas kesehatan itu sendiri. ${ }^{7}$

Reaksi anak terhadap sakit berbeda-beda sesuai tingkat perkembangan anak. ${ }^{8}$ Pada anak usia sekolah reaksi perpisahan adalah kecemasan karena berpisah dengan orang tua dan kelompok sosialnya. Pada anak usia sekolah umumnya takut pada dokter dan perawat. Pada perkembangan psikososial anak usia sekolah, hubungan dengan orang terdekat anak meluas. Anak usia sekolah mempelajari peraturan, kompetensi, dan kerja sama untuk mencapai tujuan. ${ }^{9}$

Lingkungan rumah sakit merupakan lingkungan yang baru bagi anak, sehingga anak sering merasa takut dan terancam serta tersakiti oleh tindakan yang akan dilakukan kepada dirinya. ${ }^{10}$ Pada saat dirawat di rumah sakit, anak akan mengalami berbagai perasaan yang sangat tidak menyenangkan, seperti marah, takut, cemas, sedih, dan nyeri. Untuk itu, dengan melakukan permainan anak akan terlepas dari ketegangan dan stres yang dialaminya karena dengan melakukan permainan, anak akan dapat mengalihkan rasa sakitnya pada permainannya (distraksi) dan relaksasi melalui kesenangannya melakukan permainan. ${ }^{8}$

Pop-up book identik dengan anak-anak dan mainan, merupakan media ini berisi cerita bergambar yang memiliki bentuk tiga dimensi ketika halaman buku dibuka. Terapi bermain merupakan salah satu teknik yang akan membantu penurunan ketegangan emosional yang dirasakan anak. Secara bertahap respon psikis maupun fisiologis kecemasan akan berkurang dan kepercayaan diri anak akan berkembang optimal pula. ${ }^{11}$ Hasil analisis data menggunakan Wilcoxon Rank 
Test menunjukkan perbedaan kecemasan yang signifikan (bermakna) pada anak usia sekolah (6-12 tahun) sebelum dan sesudah diberi terapi bermain dengan $\rho=0,000(\rho<0,05)$ sehingga dapat disimpulkan bahwa pemberian terapi bermain pop-up book dirasa efektif untuk menurunkan kecemasan pada anak usia sekolah (6-12 tahun).

\section{KESIMPULAN}

Pengaruh terapi bermain pop-up book terhadap kecemasan preoperatif menggunakan anestesi umum pada anak usia sekolah di RS PKU Muhammadiyah Yogyakarta. Analisis yang digunakan yaitu dengan Wilcoxon Rank Test dengan tingkat signifikansi $\rho=0,000(\rho<0,05)$. Dapat disimpulkan bahwa pemberian terapi bermain pop-up book dirasa efektif untuk menurunkan kecemasan preoperatif menggunakan anestesi umum pada anak usia sekolah di RS PKU Muhammadiyah Yogyakarta. Kecemasan preoperatif menggunakan anestesi umum sebelum diberi mainan pop-up book pada anak usia sekolah di RS PKU Muhammadiyah Yogyakarta sebagian besar menunjukkan gejala cemas sedang sebanyak 13 orang (65\%), gejala cemas berat sekali tidak ada dan paling sedikit gejala cemas ringan 1 orang (5\%). Kecemasan preoperatif menggunakan anestesi umum sesudah diberi mainan pop-up book pada anak usia sekolah di RS PKU Muhammadiyah Yogyakarta sebagian besar menunjukkan gejala cemas sedang sebanyak 10 orang (50\%), terjadi penurunan pada cemas berat dan terjadi peningkatan pada cemas ringan sebesar 9 orang (45\%).

\section{SARAN}

Hasil penelitian harapannya dapat memperkuat dan menjadi kajian ilmiah ilmu keperawatan anestesi tentang pengaruh terapi bermain pop-up book terhadap kecemasan preoperatif menggunakan anestesi umum pada anak usia sekolah.

\section{DAFTAR PUSTAKA}

1. Hockenberry, M. J., Wilson D. (2007). Wong's Nursing Care of Infants and Children. Canada: Mosby Elsevier 
2. Anggraeni, R. (2015). Pengaruh Terapi Bermain Boneka Simulasi Terapeutik Terhadap Kecemasan dan Nyeri Anak Usia Sekolah yang Menjalani Hospitalisasi Di RSUP Dr. Sardjito. Skripsi S1 Ilmu Keperawatan Universitas Gajah Mada (dipublikasikan)

3. Setyawan, D. (2014). Penerapan Media Pop-up Book untuk Meningkatkan Ketrampilan Berbicara. Jurnal FKIP UNS, (2)11

4. Kain, Z. N., Caldwell-Andrews., A. A. (2005). Preoperative Psychological Preparation of the Child for Surgery: An Update. Anesthesiologi Clinics of North America, 23:597-614

5. Fortier, M. A., Rosario, A. M., Martin, S. R., \& Kain, Z. N. (2010). Perioperative anxiety in children. Pediatr Anesth, 20 (4): 318-22

6. Setiawati, S.S. (2017). Faktor-faktor yang Berhubungan Dengan Kecemasan Pre Operasi Pada Pasien Anak di RS PKU Muhammadiyah Yogyakarta. Skripsi DIV Keperawatan Poltekkes Kemenkes Yogyakarta (tidak dipublikasikan)

7. Wong, D. L., et al. (2008). Buku Ajar Keperawatan Pediatrik. Jakarta: EGC

8. Supartini, Y. (2004). Buku Ajar Konsep Dasar Keperawatan Anak. Jakarta: EGC

9. Muscari, M. E. (2005). Panduan Belajar Keperawatan Pediatri Edisi 3. Jakarta: EGC

10. Potter, P. A., \& Perry, A. G. (2009). Fundamentals of Nursing. Australia: Mosby Elsevier

11. Pratiwi, S.Y. (2012). Penurunan Tingkat Kecemasan Anak Rawat Inap dengan Permainan Hospital Story di RSUD Kraton Pekalongan. Jurnal Ilmiah Kesehatan, 5(2), pp. 1-9 